\title{
PEMBEBANAN TANGGUNG JAWAB PERDATA KEPADA KEPALA DAERAH AKIBAT WANPRESTASI OLEH KEPALA DINAS
}

Kajian Putusan Nomor 72/PDT.G/2014/PN.TNG

\section{THE IMPOSITION OF CIVIL LIABILITY TO THE REGIONAL HEAD DUE TO DEFAULT BY THE HEAD OF OFFICE}

\author{
An Analysis of Court Decision Number 72/PDT.G/2014/PN.TNG
}

\author{
Bachtiar \\ Fakultas Hukum Universitas Pamulang \\ J1. Surya Kencana 1 Pamulang Tangerang Selatan 15417 \\ E-mail: bachtiarbaital@gmail.com \\ Tono Sumarna \\ Bagian Hukum Pemerintah Kota Tangerang Selatan \\ Jl. Maruga 1 Ciputat Tangerang Selatan 15417 \\ E-mail: tonosumri@gmail.com
}

Naskah diterima: 12 Oktober 2017; revisi: 23 Juli 2018; disetujui 6 Agustus 2018

http://dx.doi.org/10.29123/jy.v11i2.253

\section{ABSTRAK}

Wanprestasi dalam perjanjian konstruksi kerap ditemui dalam praktik, baik yang dilakukan oleh pemberi pekerjaan, maupun pihak pelaksana pekerjaan. Konsekuensinya, pihak yang melakukan wanprestasi dibebankan memulihkan kerugian yang timbul dari pelaksanaan perjanjian. Hal demikian tercermin dalam Putusan Nomor 72/PDT.G/2014/PN.TGR, di mana Kepala Dinas Kesehatan Kota Tangerang Selatan selaku pihak pemberi pekerjaan proyek terbukti melakukan wanprestasi. Menarik untuk dicermati, majelis hakim dalam putusannya justru membebankan Walikota Tangerang Selatan untuk bertanggung jawab secara keperdataan. Isu hukum yang hendak dijawab dalam tulisan ini, terkait apakah penafsiran hakim dalam Putusan Nomor 72/PDT.G/2014/PN.TNG tentang pembebanan tanggung jawab perdata kepada kepala daerah akibat wanprestasi yang dilakukan
\end{abstract}

oleh kepala dinas telah sesuai dengan ajaran hukum administrasi negara, dan ajaran hukum perdata. Untuk menjawab isu hukum tersebut, penulis menggunakan metode penelitian hukum normatif dengan bersandar pada data sekunder yang diperoleh melalui studi kepustakaan. Hasil penelitian ini menunjukkan bahwa majelis hakim telah keliru dalam menafsirkan konsep pertanggungjawaban kepala daerah. Menurut ajaran hukum administrasi negara, walikota selaku kepala daerah tidak dapat dimintai tanggung jawab secara perdata akibat wanprestasi yang dilakukan kepala dinas. Demikian pula dari perspektif Pasal 1340 KUHPerdata, walikota bukanlah merupakan pihak dalam pelaksanaan perjanjian yang dibuat oleh kepala dinas, sehingga tidak dapat dibebani tanggung jawab secara keperdataan.

Kata kunci: tanggung jawab perdata, kepala daerah, wanprestasi. 


\section{ABSTRACT}

Breach of contract in construction agreements is often found in practice, whether carried out by the employer, or the implementing party. As a consequence, the defaulting party is charged to recover losses arising from the implementation of the agreement. This was reflected in Court Decision Number 72/PDT.G/2014/ PN.TGR, which is the Head of South Tangerang City Health Office, as the project employer, has been proven in breach of contract. It is interesting to note that the panel of judges in its decision actually charged the Mayor of South Tangerang with a contractual liability. The legal issue in this paper is whether the interpretation of judges in Court Decision Number 72/PDT.G/2014/ $P N . T N G$ concerning the imposition of civil liability to the regional head due to default committed by the head of office is in accordance with the teachings of the law of state administration and civil law. To answer these issues, the author uses normative legal research methods based on secondary data obtained through literature studies. The results of the analysis show that the panel of judges has erred in interpreting the concept of regional head accountability. According to the teachings of the state administration law, the mayor as the head of the region cannot be privately liable for the default committed by the head of office. Likewise, from the perspective of Article 1340 of the Civil Code, the mayor is not a party to the implementation of the agreement made by the head of office, therefore civil liability cannot be burdened to him.

Keywords: civil liability, regional head, default.

\section{PENDAHULUAN}

\section{A. Latar Belakang}

Dalam era otonomi daerah dewasa ini pembangunan infrastruktur tetap merupakan program kerja pemerintah daerah yang sangat dikedepankan. Hal demikian disebabkan karena infrastruktur merupakan roda penggerak pertumbuhan ekonomi. Infrastruktur dipandang sebagai lokomotif pembangunan nasional dan daerah. Infrastruktur merupakan aset pemerintah yang dibangun dalam rangka pelayanan terhadap masyarakat (Solihah, 2016: 309).

Pembangunan infrastruktur itu sendiri dapat dilakukan dengan beberapa cara, bisa dengan government to government atau government dengan pihak swasta. Dalam pelaksanaan pembangunan infrastruktur antara pemerintah dan swasta, dipersyaratkan adanya perikatan tertulis antara pengguna jasa dan penyedia jasa yang berbentuk kontrak, yang dikenal dengan istilah kontrak kerja konstruksi (Slamet, 2016: 191).
Perjanjian kerja konstruksi ini merupakan dokumen yang penting dalam proyek, di mana segala hal terkait hak dan kewajiban serta alokasi risiko diatur dalam kontrak. Meskipun demikian, dalam hal pelaksanaan perjanjian kerja konstruksi, tentu besar kemungkinan timbul wanprestasi yang dilakukan oleh salah satu pihak dalam perjanjian, baik itu dilakukan oleh pemerintah selaku pemberi pekerjaan maupun pihak swasta sebagai pelaksana konstruksi. Dalam keadaan ini berlakulah ketentuan-ketentuan yang wajib dipenuhi yang timbul akibat wanprestasi, yaitu kemungkinan pemutusan perjanjian, penggantian kerugian atau pemenuhan.

Wanprestasi dalam perjanjian kerja konstruksi kerap ditemui dalam praktik, baik yang dilakukan pemerintah selaku pemberi pekerjaan dan pihak swasta selaku pelaksana pekerjaan konstruksi. Hal ini terlihat dalam Putusan Nomor 72/PDT.G/2014/PN.TNG. Dalam gugatannya penggugat mendalilkan bahwa beralasan dan berdasar hukum jika tergugat II selaku atasan 
langsung dan sebagai Pimpinan Pemerintah Kota Tangerang Selatan harus bertanggung jawab secara hukum atas semua tindakan tergugat I, sehingga layak bahwa tergugat II harus dihukum untuk menganggarkan kewajiban hukum tergugat I membayar kepada penggugat sejumlah kerugian yang dialami penggugat berdasarkan perjanjian ke dalam Tahun Anggaran 2014 Pemerintah Kota Tangerang Selatan.

Hal yang menarik untuk dikaji lebih lanjut bahwa ternyata majelis hakim dalam amarnya mengabulkan permintaan penggugat dengan menyatakan Walikota Tangerang Selatan selaku tergugat II harus ikut bertanggung jawab atas perbuatan wanprestasi dalam perjanjian kerja konstruksi yang dilakukan oleh tergugat I selaku Kepala Dinas Kesehatan yang merupakan Satuan Kerja Perangkat Daerah (SKPD) Kota Tangerang Selatan. Dalam pertimbangan hukumnya, majelis hakim berpendapat bahwa walikota (tergugat II) memiliki kedudukan selaku pengendali pemerintahan Kota Tangerang Selatan dan merupakan atasan tergugat I secara langsung.

TergugatII tidakmelakukan tugasnya dengan baik dengan cara memberikan pengarahan kepada tergugat I sehubungan dengan permasalahannya dengan penggugat, sehingga harus pula dinyatakan telah melakukan wanprestasi terhadap penggugat. Akibat perbuatan wanprestasi yang dilakukan tergugat I telah menyebabkan tergugat II selaku kepala daerah harus ikut bertanggung jawab secara keperdataan.

Konstruksi hukum dari majelis hakim yang demikian tampak tidak sebangun dengan konsep kewenangan pemerintahan menurut ajaran hukum administrasi negara. Dilihat dari organisasi kerja dalam pengadaan barang dan jasa pemerintah sebagaimana ditentukan Pasal 1 angka 5 Peraturan
Presiden Nomor 70 Tahun 2012 menyebutkan bahwa: "Pengguna Anggaran yang selanjutnya disebut PA adalah pejabat pemegang kewenangan penggunaan anggaran Kementerian/Lembaga/ Satuan Kerja Perangkat Daerah atau pejabat yang disamakan pada institusi pengguna APBN/ $A P B D$." Sementara Pasal 1 angka 7 menyebutkan bahwa: "Pejabat Pembuat Komitmen yang selanjutnya disebut PPK adalah pejabat yang bertanggung jawab atas pelaksanaan pengadaan barang/jasa." Selanjutnya Pasal 12 ayat (1) menentukan bahwa: "PPK merupakan pejabat yang ditetapkan oleh PA/KPA untuk melaksanakan pengadaan barang/jasa."

Merujuk ketentuan di atas dapat diperoleh konklusi bahwa walikota selaku kepala daerah adalah pengguna anggaran yaitu pejabat pemegang kewenangan penggunaan anggaran yang kewenangannya diperoleh secara atribusi melalui Peraturan Presiden Nomor 70 Tahun 2012. Untuk melaksanakan pengadaan barang dan jasa tersebut, pengguna anggaran melimpahkan kewenangannya kepada pejabat pembuat komitmen yakni Kepala Dinas Kesehatan Kota Tangerang Selatan sebagai unsur SKPD Kota Tangerang Selatan. Sehingga tanggung jawab atas pelaksanaan pengadaan barang dan jasa tersebut telah beralih kepada Kepala Dinas Kesehatan Kota Tangerang Selatan selaku pejabat pembuat komitmen. Kewenangan pejabat pembuat komitmen muncul karena adanya delegasi kewenangan dari pengguna anggaran sebagaiman disebutkan dalam ketentuan Pasal 12 ayat (1) Peraturan Presiden Nomor 70 Tahun 2012.

Dalam kajian hukum administrasi negara, mengetahui sumber dan cara memperoleh kewenangan organ pemerintahan ini penting. Dikatakan demikian karena berkenaan dengan 
pertanggungjawaban hukum atas penggunaan kewenangan tersebut. Menurut Ridwan HR (2014: 109), "Setiap pemberian kewenangan kepada pejabat pemerintahan tertentu tersirat pertanggungjawaban dari pejabat yang bersangkutan." Ketika suatu kewenangan itu telah dilimpahkan atau didelegasikan, maka pemberi wewenang telah lepas dari tanggung jawab hukum atau tuntutan pihak ketiga jika dalam penggunaan wewenang itu menimbulkan kerugian pada pihak lain.

Berdasarkan uraian di atas dan dihubungkan dengan amar putusan, tampak terjadi inkonsistensi teoritik dari konstruksi hukum hakim terkait pembebanan tanggung jawab hukum secara keperdataan kepada tergugat II akibat wanprestasi yang dilakukan oleh tergugat I. Hal inilah yang memotivasi penulis untuk melakukan penelitian ini lebih lanjut.

\section{B. Rumusan Masalah}

Berdasarkan uraian latar belakang di atas, maka rumusan masalah yang hendak dijawab dalam penelitian ini adalah apakah tafsir hakim terkait pembebanan tanggung jawab kepada walikota akibat wanprestasiyang dilakukankepala dinas pada pelaksanaan perjanjian konstruksi dalam Putusan Nomor 72/PDT.G/2014/PN.TNG telah sesuai dengan konsep kewenangan menurut ajaran hukum administrasi negara dan ajaran hukum perdata?

\section{Tujuan dan Kegunaan}

Tujuan penelitian ini adalah untuk menganalisis dan menemukan kesesuaian tafsir hakim terkait pembebanan tanggung jawab perdata kepada kepala daerah akibat wanprestasi yang dilakukan oleh kepala dinas dalam perjanjian kerja konstruksi dihubungkan dengan konsep kewenangan menurut ajaran hukum administrasi negara dan ajaran hukum perdata. Penelitian ini diharapkan dapat digunakan sebagai referensi yang dapat ikut menunjang perkembangan ilmu pengetahuan. Penelitian ini juga diharapkan dapat memberikan kontribusi praktis yaitu menjadi pegangan dan pedoman bagi praktisi hukum terutama bagi hakim dalam melakukan suatu penafsiran hukum terhadap kasus yang bersinggungan antara dua disiplin ilmu hukum.

\section{Tinjauan Pustaka}

\section{Konsep Tanggung Jawab Hukum}

Pelaksanaan suatu hak dan kewajiban hukum selalu menuntut adanya tanggung jawab hukum. Pelaksanaan setiap wewenang yang dibebankan dalam suatu jabatan selalu menuntut adanya tanggung jawab. Setiap pemangku jabatan memiliki kebebasan bertindak, namun kebebasannya dibatasi oleh kehendak pemberi wewenang yang telah disepakati dan diwajibkan kepadanya untuk dilaksanakan. Dengan perkataan lain, kewajiban para pihak yang telah ditentukan dalam suatu perjanjian merupakan suatu kausa yang melahirkan tanggung jawab, sebagai suatu kewajiban bagi para pihak yang terikat dalam suatu perjanjian. Hal demikian didasarkan pada prinsip pacta sun servanda, di mana perjanjian yang dibuat berlaku sebagai undang-undang.

Menurut Kelsen (Bachtiar, 2017: 57), sebuah konsep yang berhubungan dengan konsep kewajiban hukum adalah konsep pertanggungjawaban hukum. Menurutnya, seseorang bertanggung jawab secara hukum atas perbuatan tertentu atau bahwa dia memikul tanggung jawab hukum berarti bahwa dia bertanggung jawab atas suatu sanksi bila 
perbuatannya bertentangan. Terkait hal ini, Pound (Firdaus, 2007: 15) menguraikan pendapatnya sebagai berikut:

“...yang menjadi titik tolak dari pertanggungjawaban adalah tindakan-tindakan personal, apakah pertanggungjawaban karena tindakan yang merugikan orang lain atau kewajiban melaksanakan janji. Oleh sebab itu, bagi Pound pertanggungjawaban merupakan efek yang diberikan oleh ex delicto tetapi juga dilaksanakan karena ex contractu, yang berarti bahwa seseorang boleh menagih dan seorang lainnya tunduk kepada penagihan."

Bagi Nasution (2011: 133), tanggung jawab hukum itu sendiri dapat bermakna sebagai pertanggungjawaban yang didasarkan atas the rule of the game atau the rule of law. Dengan demikian, tanggung jawab hukum merupakan tanggung jawab yang didasarkan atas kehendak norma-norma hukum yang tentunya bersumber pada berbagai peraturan perundang-undangan, termasuk yang bersumber dari adanya suatu perikatan yang telah dituangkan ke dalam suatu perjanjian/kontrak.

\section{Konsep Kewenangan Pemerintahan}

Kewenangan merupakan konsep penting dalam hukum tata pemerintahan, karena pemerintah baru dapat menjalankan fungsinya atas dasar wewenang yang diperolehnya. Keabsahan tindakan pemerintah diukur berdasarkan wewenang yang diatur dalam peraturan perundang-undangan. Oleh karena itu, dalam telaah hukum tata pemerintahan, kewenangan memiliki kedudukan penting dan merupakan "konsep inti dalam hukum tata negara dan hukum administrasi negara" seperti ditegaskan Stronik \& Steenbeek (Ridwan HR, 2014: 99).
Wewenang itu sendiri menurut Nicolai (Ilmar, 2014: 102) adalah kemampuan untuk melakukan tindakan atau perbuatan hukum tertentu, yakni tindakan atau perbuatan yang dimaksudkan untuk menimbulkan akibat hukum dan mencakup mengenai timbul dan lenyapnya akibat hukum. Hal demikian ditegaskan pula oleh Marbun (Hidjaz, 2010: 35) bahwa wewenang adalah kemampuan bertindak yang diberikan oleh undang-undang yang berlaku untuk melakukan hubungan dan perbuatan hukum. Dengan demikian, wewenang pemerintahan tidak lain merupakan kekuasaan yang ada pada pemerintah untuk menjalankan fungsi dan tugasnya berdasarkan peraturan perundang-undangan.

Secara teoritis, kewenangan yang bersumber dari peraturan perundang-undangan ini diperoleh melalui tiga cara, yaitu: atribusi, delegasi, dan mandat. Menurut Hadjon (Suhendar, 2015: 96) ketiganya adalah sumber kewenangan yang berkaitan dengan suatu jabatan (ambt) sebagai dasar bagi pemerintah untuk melakukan perbuatan hukum publik. Selanjutnya Ridwan HR (2014: 103-104) mengungkapkan bahwa di antara ketiga cara tersebut, delegasi merupakan konsep aliran kewenangan yang paling banyak terjadi dalam pemerintahan. Delegasi merupakan bentuk pelimpahan wewenang oleh organ pemerintahan yang telah diberi wewenang kepada organ lain yang akan melaksanakan wewenang yang telah dilimpahkan itu sebagai wewenangnya sendiri. Dengan wewenang itu, penerima wewenang dapat menggunakan dan mengambil keputusan dengan tanggung jawabnya sendiri. Artinya dalam penyerahan wewenang melalui delegasi ini, pemberi wewenang telah lepas dari tanggung jawab hukum atau tuntutan pihak ketiga, jika dalam penggunaan wewenang itu menimbulkan kerugian pada pihak lain. 
Mengetahui sumber dan cara memperoleh kewenangan organ pemerintahan ini penting, karena berkenaan dengan pertanggungjawaban hukum dalam penggunaan wewenang tersebut. Dalam setiap pemberian kewenangan kepada pejabat pemerintahan tertentu tersirat pertanggungjawaban dari pejabat yang bersangkutan. Ketika suatu kewenangan itu telah dilimpahkan atau didelegasikan, maka pemberi wewenang telah lepas dari tanggung jawab hukum atau tuntutan pihak ketiga jika dalam penggunaan wewenang itu menimbulkan kerugian pada pihak lain.

Berdasarkan konsep wewenang dari pemerintah sebagaimana diuraikan di atas, dapat ditegaskan bahwa kaidah-kaidah hukum yang mengatur tentang pelaksanaan wewenang pemerintah menjadi prinsip hukum yang mengatur tata pemerintahan dan tata kehidupan masyarakat dan menjadi dasar validitasnya di bidang pemerintahan. Artinya, kaidah hukum tata pemerintahan itu merupakan sarana untuk melindungi kepentingan-kepentingan masyarakat.

\section{Konsep Wanprestasi dalam Perjanjian Konstruksi}

Tanggung jawab hukum atas dasar wanprestasi didasari adanya hubungan kontraktual. Hubungan kontraktual timbul baik karena perjanjian atau karena undang-undang. Menurut Pasal 1313 KUHPerdata, perjanjian adalah suatu perbuatan dengan mana satu orang atau lebih mengikatkan dirinya terhadap satu orang lain atau lebih (Raharjo, 2009: 41). Sementara Pasal 1 angka 6 Undang-Undang Nomor 18 Tahun 1999 tentang Jasa Konstruksi merumuskan perjanjian atau kontrak kerja konstruksi sebagai keseluruhan dokumen yang mengatur hubungan hukum antara pengguna jasa dan penyedia jasa dalam penyelenggaraan pekerjaan konstruksi.

Menurut ajaran hukum perdata, apabila salah satu pihak dalam perjanjian kerja konstruksi tidak melaksanakan prestasinya maka dikatakan wanprestasi. Wanprestasi itu sendiri dalam berbagai literatur dimaknai sebagai tidak memenuhi kewajiban sebagaimana diterapkan perikatan atau perjanjian, tidak dipenuhinya kewajiban dalam suatu perjanjian, dapat disebabkan dua hal, yaitu kesalahan debitur baik disengaja maupun karena kelalaian dan karena keadaan memaksa atau overmacht/force majure (Meliala, 2012: 175). Sementara Pasal 1243 KUHPerdata merumuskan wanprestasi sebagai berikut:

"Penggantian biaya, rugi dan bunga tidak dipenuhinya suatu perkataan, barulah mulai diwajibkan, apabila yang berutang, setelah dinyatakan lalai memenuhi perikatannya, tetap melalaikannya, atau jika yang harus diberikan atau dibuatnya, hanya dapat diberikan atau dibuat dalam tenggang waktu yang telah dilampaukan."

Apabila pemerintah selaku pemberi pekerjaan melakukan wanprestasi, maka pihak pemborong pekerjaan dapat mengajukan gugatan perbuatan wanprestasi ke pengadilan. Kedudukan pemerintah dalam perjanjian pemborongan adalah sebagai wakil dari badan hukum keperdataan, sehingga dapat dimintai tanggung jawab secara keperdataan. Hal demikian ditegaskan Ridwan HR (2014: 88) sebagai berikut:

"Ketika pemerintah bertindak di lapangan keperdataan dan tunduk pada peraturan hukum perdata, pemerintah bertindak sebagai wakil dari badan hukum, bukan wakil dari jabatan. Oleh karena itu, kedudukan pemerintah dalam pergaulan hukum keperdataan tidak berbeda dengan seseorang atau badan hukum privat, tidak 
memiliki kedudukan yang istimewa, dan dapat menjadi pihak dalam sengketa keperdataan dengan kedudukan yang sama dengan seseorang atau badan hukum perdata (equality before the law) dalam peradilan umum."

\section{METODE}

Penelitian ini didesain dengan pendekatan penelitian hukum normatif, karena ditujukan untuk menemukan dan merumuskan argumentasi hukum melalui analisis terhadap pokok permasalahan (Wiradipradja, 2015: 26). Desain penelitian yang demikian memungkinkan peneliti untuk melakukan kritik terhadap tafsir/ interpretasi hukum hakim dalam putusannya terkait pembebanan tanggung jawab kepada kepala daerah akibat wanprestasi yang dilakukan kepala dinas dalam perjanjian kerja konstruksi.

Adapun pendekatan yang digunakan dalam penelitian ini adalah pendekatan kasus, pendekatan perundang-undangan, dan pendekatan konseptual. Bahan-bahan hukum dalam penelitian ini dikumpulkan melalui studi kepustakaan yang lebih menekankan pada teknik penelusuran dokumen, yakni bahan-bahan tertulis yang berisi informasi tentang fenomena objek yang diteliti. Bahan-bahan hukum yang terkumpul selanjutnya dianalisis dengan menggunakan analisis kualitatif (Afrizal, 2016: 178-180).

Data yang telah diorganisir, dinterpretasi dengan menggunakan interpretasi hermeneutika hukum. Pendekatan hermeneutika hukum digunakan sebagai upaya membangun penafsiran hukum yang komprehensif, sehingga interpretasi hukum yang dikonstruksikan hakim tidak terjebak pada penafsiran teks semata, melainkan mempertimbangkan keterkaitan antara teks, konteks, dan kontekstualiasasinya. Dalam perspektif demikian, kajian hermeneutika hukum mengajak para pengkaji hukum agar menggali dan meneliti makna-makna hukum dari perspektif para pengguna dan/atau para pencari keadilan (Musyahadah, 2013: 300).

\section{HASIL DAN PEMBAHASAN}

\section{A. Kesesuaian Tafsir Hakim dengan Konsep Kewenangan Menurut Ajaran Hukum Administrasi Negara}

Perkara ini bermula dari adanya gugatan wanprestasi yang diajukan oleh PT. TJP selaku penggugat yang diwakili secara sah oleh LS yang bertindak dalam kedudukannya selaku direktur utama, ditujukan kepada Kepala Dinas Kesehatan Kota Tangerang Selatan selaku tergugat I dan Walikota Tangerang Selatan selaku tergugat II. Gugatan penggugat terhadap tergugat I dan tergugat II diajukan dengan alasan para tergugat telah melakukan wanprestasi terkait pelaksanaan Perjanjian Pekerjaan Pembangunan Pusat Pelayanan Kesehatan Terpadu Nomor DPA 1.02.01.35.001.5.2, Lokasi Setu Kota Tangerang Selatan, dengan jangka waktu pelaksanaan 190 hari kelender, berakhir pada 31 Desember 2013, dengan nilai kontrak Rp.14.303.780.000,sebagaimana tertuang dalam Surat Perjanjian Nomor 027/06-10/KKPK/Dinkes/VI/2013 tertanggal 25 Juni 2013 yang ditandatangani penggugat dan tergugat I.

Hakim menyatakan Pemerintah Kota Tangerang Selatan terbukti melakukan wanprestasi dan membebani walikota selaku kepala daerah untuk bertanggung jawab secara keperdataan akibat wanprestasi yang dilakukan kepala dinas. Adapun putusan hakim tersebut didasarkan pada pertimbangan bahwa tergugat II merupakan pemegang kekuasaan 
keuangan daerah dan mempunyai kewenangan penyelenggaraan keuangan daerah sesuai dengan ketentuan Pasal 1 ayat (14) Peraturan Menteri Dalam Negeri Nomor 13 Tahun 2006. Sedangkan tergugat I dalam kedudukannya selaku kepala dinas merupakan pengguna anggaran/pengguna barang sesuai dengan ketentuan Pasal 1 ayat (10) Peraturan Menteri Dalam Negeri Nomor 13 Tahun 2006.

Tergugat I dalam pelaksanaan tugasnya selaku pengguna anggaran/pengguna barang, bertanggung jawab secara formal dan material kepada tergugat II sesuai dengan ketentuan Pasal 54 Undang-Undang Nomor 1 Tahun 2004 jo. Pasal 10 huruf m Peraturan Pemerintah Nomor 58 Tahun 2005 tentang Pengelolaan Keuangan Daerah.

Merujuk pada tafsir yang demikian, hakim pada akhirnya berpendapat bahwa apabila tergugat I dalam melaksanakan tugasnya telah melakukan perbuatan melawan hukum atau melakukan wanprestasi kepada pihak lain, maka yang bertanggung jawab tidak saja tergugat I, tetapi juga tergugat II sebagai pemegang kekuasaan dan penyelenggaraan keuangan daerah. Sebelum menganalisis tafsir hakim tersebut, perlu dijelaskan terlebih dahulu bahwa dalam konteks welfare state, pemerintah secara yuridis diberikan keleluasaan untuk melakukan berbagai tindakan hukum, baik dalam lapangan hukum publik maupun dalam lapangan hukum privat. Keleluasaan bertindak ini merupakan wujud dari eksistensi dan peran pemerintah untuk melayani masyarakat, menciptakan kondisi yang memungkinkan setiap anggota masyarakat mengembangkan kemampuan dan kreativitasnya demi mencapai kemajuan bersama (Rasjid, 2007: 11).
Pemerintah berperan memberikan pelayanan demi kesejahteraan rakyat dengan sistem peradilan yang baik dan sistem pemerintahan yang dapat dipertanggungjawabkan kepada publik (Tahir, 2015:11). Singkatnya, peran pemerintah yang utama adalah menyelenggarakan pelayanan umum sebagai wujud dari tugas umum pemerintahan untuk mewujudkan kesejahteraan masyarakat. Bagi Newton \& Van Deth (2015: 397), pemerintah ada untuk menyelesaikan masalah dan untuk itulah pemerintah harus mengambil keputusan. Meskipun diberikan keleluasaan untuk bertindak dalam rangka perwujudan kesejahteraan umum (bestuurzorg), berbagai tindakan itu hanya dapat dilakukan berdasarkan adanya kewenangan yang ditentukan oleh peraturan perundang-undangan sebagai bentuk keabsahan tindakan dari pemerintah. Tanpa adanya wewenang pemerintahan, maka tentunya pemerintah tidak akan dapat melakukan suatu tindakan atau perbuatan pemerintahan. Hal demikian diungkap Ilmar (2014: 108) sebagai berikut:

“...pemerintah tidak akan mungkin melakukan suatu tindakan atau perbuatan berupa pengambilan suatu keputusan atau kebijakan tanpa dilandasi atau disertai dengan wewenang pemerintah. Jika hal tersebut dilakukan, maka tindakan atau perbuatan pemerintahan yang dimaksud dapat dikategorikan sebagai sebuah tindakan atau perbuatan yang tanpa dasar alias perbuatan yang sewenangwenang (cacat hukum). Oleh karena itu, sifat dari wewenang pemerintahan perlu ditetapkan dan ditegaskan agar tidak terjadi penyalahgunaan wewenang pemerintahan dan/atau tindakan atau perbuatan yang sewenang-wenang."

Akhirnya berbagai tindakan hukum pemerintah mengandung pembawaan untuk dipertanggungjawabkan dalam batas-batas yang ditentukan oleh hukum itu sendiri dan rasa 
keadilan masyarakat. Karena lingkup tindakan hukum pemerintah dalam dua lapangan hukum, maka secara konseptual tanggung jawab hukum akan merujuk pada tanggung jawab dalam bidang hukum publik, yaitu tanggung jawab bidang administrasi negara dan tanggung jawab pidana; dan tanggung jawab hukum privat yaitu tanggung jawab hukum perdata. Hal demikian ditegaskan Van Apeldoorn (2000: 174) bahwa dilihat dari aspek lingkup bidang hukum, maka secara umum konsep tanggung jawab hukum akan merujuk pada tanggung jawab hukum dalam ranah hukum publik dan tanggung jawab hukum dalam ranah hukum privat.

Ditegaskan Djojodirdjo (1979: 13) bahwa tanggung jawab hukum dalam ranah hukum publik misalkan tanggung jawab administrasi negara dan tanggung jawab hukum pidana. Sementara itu terkait dengan tanggung jawab dalam ranah hukum privat adalah tanggung jawab hukum dalam hukum perdata dapat berupa tanggung jawab berdasarkan wanprestasi dan tanggung jawab berdasarkan perbuatan melawan hukum. Dengan pemahaman yang demikian, maka dapat ditegaskan bahwa tanggung jawab hukum pemerintah atas berbagai tindakan yang dilakukan dalam kerangka bestuurzorg harus dibedakan dalam lapangan hukum mana pemerintah bertindak. Jika pemerintah bertindak dalam lapangan hukum publik, maka tanggung jawab hukum pemerintah terkait tanggung jawab hukum administrasi negara dan tanggung jawab pidana, sedangkan jika pemerintah bertindak dalam lapangan hukum privat, maka tanggung jawab hukum pemerintah terkait tanggung jawab keperdataan.

Dalam konteks keperdataan, tangggung jawab tersebut lahir karena adanya perjanjian atau hubungan kontraktual dan karena undang- undang. Tanggung jawab hukum perdata dapat diajukan atas dasar, yaitu: (i) adanya perbuatan melawan hukum sebagaimana ditentukan dalam Pasal 1365 KUHPerdata yang pada dasarnya menentukan bahwa barang siapa melakukan perbuatan yang membawa kerugian kepada orang lain mewajibkan orang yang salah karena salahnya mengganti kerugian tersebut; dan (ii) adanya wanprestasi yaitu tidak memberikan prestasi sama sekali, terlambat memberikan prestasi, melakukan prestasi tidak menurut ketentuan yang telah ditetapkan dalam perjanjian yang dilakukan salah satu pihak dalam perjanjian sebagaimana ditentukan dalam Pasal KUHPerdata.

Hal lain yang perlu ditegaskan pula bahwa tanggung jawab hukum pemerintah sebagai konsekuensi dari berbagai tindakan yang dilakukan dalam kerangka menjalankan fungsifungsi pemerintahan yang menjadi lingkup kewenangannya memiliki karakteristik tersendiri yaitu dalam batas-batas kewenangan yang dimilikinya.

Dalam konteks ini, pemahaman atas sumber dan cara memperoleh kewenangan organ pemerintahan menjadi kata kunci untuk dapat menentukan siapa yang bertanggung jawab atas tindakan hukum pemerintah tersebut, termasuk dalam lapangan hukum keperdataan. Hal demikian ditegaskan secara kritis oleh Ridwan HR (2014: 105):

Dalam kajian hukum administrasi negara, mengetahui sumber dan cara memperoleh wewenang organ pemerintahan ini penting, karena berkenaan dengan pertanggungjawaban hukum (rechtelijke verantwording) dalam penggunaan wewenang tersebut, seiring dengan salah satu prinsip dalam negara hukum "geen bevogheid zonder verantwoordelijkheid" atau "there is no authority without responsibility" (tidak ada kewenangan tanpa 
pertanggungjawaban). Di dalam setiap pemberian kewenangan kepada pejabat pemerintahan tersirat pertanggungjawaban dari pejabat yang bersangkutan.

Dalam berbagai literatur hukum administrasi negara menentukan bahwa kewenangan mempunyai dua macam sifat, yaitu kewenangan yang bersifat atributif dan bersifat distributif. Kewenangan yang bersifat atributif adalah kewenangan bersifat melekat maksudnya kewenangan yang langsung diberikan oleh undang-undang, sedangkan kewenangan yang bersifat distributif adalah kewenangan yang misalnya diberikan oleh atasan kepada bawahan dan hanya bersifat sementara.

Adapun perbedaan antara kewenangan atributifdankewenangan distributifadalahterletak pada pertanggungjawabannya, kewenangan atributif memiliki tanggung jawab yang melekat kepada aparat atau pejabat yang langsung ditunjuk oleh undang-undang. Sedangkan kewenangan distributif terbagi dua yaitu mandat dan delegasi, untuk mandat pertanggungjawabannya melekat pada pemberi wewenang dan untuk delegasi pertanggungjawabannya berpindah kepada si penerima wewenang.

Merujuk pada konsep yang demikian dan dikaitkan dengan tafsir hakim dalam putusannya, penulis berpendapat bahwa majelis hakim telah keliru dalam pertimbangan hukumnya yang menyatakan bahwa tergugat II dalam hal ini walikota untuk ikut bertanggung jawab atas perbuatan wanprestasi yang dilakukan oleh kepala dinas. Majelis hakim keliru dalam memahami konsep tanggung jawab hukum pemerintah dalam konteks hukum administrasi negara.

Majelis hakim dalam pertimbangan hukumnya mengkonstruksikan fakta hukum yang ada secara keliru dengan menggunakan penafsiran analogi bahwa karena kepala dinas adalah bagian dari perangkat daerah di mana walikota adalah kepala pemerintahannya, sehingga perbuatan wanprestasi yang dilakukan kepala dinas harus pula dapat dimintai pertanggungjawabannya kepada walikota. Dengan kata lain kepala dinas adalah anak buah dari walikota, sehingga apabila kepala dinas berbuat wanprestasi maka sang bos juga harus bertanggung jawab. Tafsir hakim yang demikian sangat tidak beralasan dan mengadaada serta sekaligus menunjukkan majelis hakim tidak memahami konsep kewenangan dalam hukum administrasi negara.

Menurut penulis, interpretasi hukum hakim terkait pembebanan tanggung jawab perdata kepada walikota tidak sejalan dengan prinsipprinsip tanggung jawab yang dianut dalam hukum administrasi negara. Mengikuti pola interpretasi hermeneutika hukum, majelis hakim semestinya mencermati dengan benar teks yuridis yang mendasari fakta hukumnya sebelum memberikan putusan.

Bahwa pertama kali yang harus dilakukan hakim adalah menemukan sumber dan aliran kewenangan bagi walikota dalam teks yuridisnya dan selanjutnya dihubungkan dengan konteks yuridisnya untuk menentukan apakah padanya dapat dimintai tanggung jawab hukum. Argumentasi yang demikian berangkat dari pemikiran bahwa aktivitas interpretasi dengan pendekatan hermeneutika hukum tidak semata bersandar pada teks yuridis semata, melainkan juga ditilik dari konteks dan kontekstualisasinya.

Rujukan majelis hakim tentunya bersumber pada ketentuan-ketentuan yang diatur dalam Peraturan Pemerintah Nomor 58 Tahun 2005 tentang Pengelolaan Keuangan Daerah dan 
Peraturan Menteri Dalam Negeri Nomor 13 Tahun 2006 tentang Pedoman Pengelolaan Keuangan Daerah sebagai peraturan turunannya. Menurut Pasal 5 ayat (1) Peraturan Pemerintah Nomor 58 Tahun 2005 jo. Pasal 5 ayat (1) Peraturan Menteri Dalam Negeri Nomor 13 Tahun 2006 disebutkan bahwa: "Kepala daerah selaku kepala pemerintah daerah adalah pemegang kekuasaan pengelolaan keuangan daerah dan mewakili pemerintah daerah dalam kepemilikan kekayaan daerah yang dipisahkan."

Ditegaskan pula dalam Pasal 1 angka 14 Peraturan Menteri Dalam Negeri Nomor 13 Tahun 2006 bahwa "Pemegang kekuasaan pengelolaan keuangan daerah adalah kepala daerah yang karena jabatannya mempunyai kewenangan menyelenggarakan keseluruhan pengelolaan keuangan daerah." Kepala daerah di sini adalah gubernur bagi daerah provinsi atau bupati bagi daerah kabupaten atau walikota bagi daerah kota sebagaimana ditulis dalam Pasal 1 angka 13. Sementara Satuan Kerja Perangkat Daerah (SKPD) adalah perangkat daerah pada pemerintah daerah selaku pengguna anggaran/ pengguna barang sebagaimana diatur dalam Pasal 1 angka 10.

Merujuk pada teks yuridis demikian, diperoleh konklusi bahwa walikota adalah pemegang kekuasaan keuangan daerah. Namun dalam perspektif makna yang terkandung pada teks yuridisnya, kekuasaan tersebut harus dikontekstualisasikan dalam makna "karena jabatannya" yang diberikan kewenangan untuk menyelenggarakan keseluruhan pengelolaan keuangan daerah. Pada titik inilah majelis hakim terlihat hanya memfokuskan teks yuridisnya ke dalam pertimbangan hukumnya dan hal itu menjadi benar adanya tanpa mempertimbangkan kontekstualisasi dari teks yuridisnya.
Ditilik dari aktivitas interpretasi hermenutika hukum, titik fokus yang seperti itu membuat simpulan majelis hakim menjadi tidak lengkap dan terkesan terlalu disimplifikasikan dan terjebak pada teks yuridis yang parsial. Majelis hakim lupa bahwa kekuasaan pengelolaan keuangan daerah yang menjadi kekuasaan walikota itu berdasarkan ketentuan Pasal 5 ayat (3) huruf c Peraturan Menteri Dalam Negeri Nomor 13 Tahun 2006, yaitu: “...dilimpahkan sebagian atau keseluruhannya kepada Kepala SKPD selaku pejabat pengguna anggaran/ pengguna barang." Bahkan menurut ayat (4), pelimpahan tersebut ditetapkan dengan keputusan kepala daerah berdasarkan prinsip pemisahan kewenangan yang memerintahkan, menguji, dan yang menerima atau mengeluarkan uang.

Merujuk pada berbagai ketentuan di atas, menjadi terang bahwa memang benar secara yuridis yang memiliki kekuasaan atas pengelolaan keuangan daerah adalah walikota, namun dalam pelaksanaannya telah dilimpahkan atau didelegasikan kepada kepala dinas. Dengan adanya pendelegasian kewenangan ini dari walikota kepada kepala dinas, maka yang bertanggung jawab secara hukum atas semua pengelolaan keuangan daerah dibebankan kepada kepala dinas selaku pengguna anggaran/ pengguna barang.

Hal demikian didasarkan pada karakteristik dari pendelegasian wewenang menurut ajaran hukum administrasi negara sebagaimana dikemukakan Ridwan HR (2014: 108) bahwa pada delegasi tidak ada pencipta wewenang, namun hanya ada pelimpahan wewenang dari pejabat yang satu kepada pejabat yang lainnya. Tanggung jawab yuridis tidak lagi berada pada pemberi delegasi (delegans), tetapi beralih pada penerima delegasi (delegataris). Dengan kata lain, 
ketika suatu kewenangan telah dilimpahkan dari pemegang delegasi kepada penerima delegasi, maka secara mutatis mutandis telah terjadi peralihan tanggung jawab. Bahkan Hadjon et al. (1993: 8) secara kritis mengungkapkan bahwa ketika wewenang tersebut telah berpindah, maka pemberi delegasi tidak dapat lagi menggunakan wewenang itu, kecuali setelah ada pencabutan dengan berpegang pada asas contrarius actus.

Bersandar pada interpretasi hermeneutika hukum, maka dapat dikatakan bahwa tafsir hakim yang demikian tidak beralasan menurut hukum jika perbuatan wanprestasi yang dilakukan oleh kepala dinas juga dibebankan kepada walikota untuk bertanggung jawab, sebagaimana pendapat majelis hakim dalam pertimbangan hukumnya. Walikota selaku tergugat II semestinya dibebaskan dari pembebanan tanggung jawab hukum perdata karena menurut hukum kewenangan yang dimiliki walikota dalam pengelolaan keuangan daerah telah dilimpahkan kepada kepala dinas selaku pengguna anggaran/pengguna barang.

Majelis hakim pun telah keliru dalam menafsirkan ketentuan Pasal 54 Undang-Undang Nomor 1 Tahun 2004 tentang Perbendaharaan Negara yang menyatakan pengguna anggaran bertanggung jawab secara formal dan material kepada presiden/gubernur/bupati/walikota atas pelaksanaan kebijakan anggaran yang berada dalam penguasaannya, jo. Pasal 10 huruf $\mathrm{m}$ Peraturan Pemerintah Nomor 58 Tahun 2005 yang menyatakan pejabat pengguna anggaran/ pengguna barang bertanggung jawab atas pelaksanaan tugasnya kepada kepala daerah melalui sekretaris daerah.

Semestinya jika merujuk pada kedua ketentuan itu, maka menjadi benar bahwa yang bertanggung jawab atas pelaksanaan pengelolaan keuangan daerah adalah kepala dinas selaku pengguna anggaran/pengguna barang, baik secara formal maupun secara materiil. Bukan seperti pendapat majelis hakim yang menyatakan walikota selaku tergugat II ikut bertanggung jawab. Oleh karena itu tidak beralasan dan mengada-ada pendapat majelis hakim yang demikian. Bagaimana mungkin pasal-pasal yang dikonstruksikan majelis hakim menentukan bahwa yang bertanggung jawab dalam penggunaan anggaran adalah kepala dinas, namun juga mengikutsertakan tergugat II ikut bertanggung jawab.

Hal demikian membuktikan bahwa majelis hakim tidak cermat dalam menafsirkan bunyi pasal sehingga konstruksi hukumnya menjadi tidak beralasan menurut hukum.

\section{B. Kesesuaian Tafsir Hakim dengan Ajaran Hukum Perdata}

Dalam perspektif ajaran hukum perdata, perbuatan wanprestasi yang dilakukan kepala dinas (tergugat I) juga tidak dapat dibebankan kepada walikota (tergugat II). Hal ini sesuai dengan ketentuan Pasal 1340 KUHPerdata yang menentukan bahwa: "Suatu perjanjian hanya berlaku antara pihak-pihak yang membuatnya. Suatu perjanjian tidak dapat membawa rugi kepada pihak-pihak ketiga; tidak dapat pihakpihak ketiga mendapat manfaat karenanya, selain dalam hal yang diatur dalam Pasal 1317."

Mengacu pada pasal tersebut, tergugat II dalam kapasitas jabatannya selaku walikota tidak dapat dibebani tanggung jawab hukum untuk membayar ganti kerugian yang timbul akibat wanprestasi dari Surat Perjanjian Nomor 027/0610/KKPK/Dinkes/VI/2013 yang dibuat dan ditandatangani oleh Pejabat Pembuat Komitmen 
untuk dan atas nama Dinas Kesehatan selaku pengguna anggaran/pengguna barang dengan PT. TJP.

Majelis hakim telah keliru dalam memahami fakta bahwa penandatanganan kontrak pemborongan yang dilakukan oleh kepala dinas selaku pejabat pembuat komitmen untuk dan atas nama Pemerintah Kota Tangerang Selatan. Majelis hakim memandang secara hukum yang mempunyai proyek pekerjaan konstruksi pembangunan Pusat Pelayanan Kesehatan Terpadu di Kota Tangerang Selatan adalah pemerintah Kota Tangerang Selatan yang dalam hal ini sebagai kepala pemerintahannya adalah Walikota Tangerang Selatan yang dalam pekerjaan proyek tersebut dilaksanakan oleh pejabat pembuat komitmen (kepala dinas).

Kapasitas kepala dinas untuk menandatangani perjanjian pemborongan dimaksud meskipun bertindak untuk dan atas nama Pemerintah Kota Tangerang Selatan, namun tindakan tersebut didasarkan pada tugas yang dibebankan kepadanya yang bersumber dari kewenangan yang didelegasikan oleh walikota selaku kepala daerah. Hal demikian telah ditentukan dalam Pasal 10 huruf g Peraturan Menteri Dalam Negeri Nomor 13 Tahun 2006 yang menyatakan bahwa Kepala SKPD (Kepala Dinas Kesehatan Kota Tangerang Selatan) selaku pengguna anggaran/pengguna barang mempunyai tugas mengadakan ikatan/perjanjian kerja sama dengan pihak lain dalam batas anggaran yang telah ditetapkan.

Kapasitas kepala dinas untuk menandatangani perjanjian pekerjaan proyek ini harus dimaknai sebagai bagian kewenangan yang melekat padanya berdasarkan pelimpahan wewenang yang diberikan oleh walikota selaku kepala daerah, sehingga pelaksanaan tugas dan wewenang untuk menandatangani surat perjanjian tersebut tetap dalam kerangka tanggung jawabnya yang tidak dapat dialihkan kepada pemberi kewenangan tersebut, dalam hal ini kepada walikota selaku kepala daerah.

Walikota tidak memiliki kapasitas untuk bertindak dan mencampuri pelaksanaan tugas kepala dinas untuk mengadakan ikatan/perjanjian dengan pihak lain sebagai bentuk pelaksanaan anggaran yang dimiliki SKPD-nya berdasarkan mekanisme penganggaran. Justru menurut kaidah dalam hukum pemerintahan, pelaksanaan tugas dan wewenang dari kepala dinas mengandung pembawaan harus senantiasa dilaporkan kepada walikota sebagai bentuk pertanggungjawaban atas kewenangan yang telah dilimpahkan atau didelegasikan oleh walikota selaku top executive di tingkat pemerintah kota.

Pemahaman yang demikian, dalil yang dikemukakan oleh walikota selaku tergugat II terkait ketentuan Pasal 1340 KUHPerdata merupakan dalil yang beralasan sehingga patut bagi majelis hakim untuk mempertimbangkannya dalam pertimbangan hukumnya. Pasal 1340 KUHPerdata menjadi pembatas daya ikat dan keberlakukan perjanjian bagi para pihak, yakni sebatas bagi para pihak yang membuatnya. Ketentuan inilah yang dikenal dengan asas perjanjian bersifat tertutup. Dalam hal ini, meskipun walikota selaku kepala daerah yang bertanggung jawab secara keseluruhan atas pengelolaan keuangan daerah, namun walikota bukanlah merupakan pihak dalam pelaksanaan ikatan/perjanjian yang dibuat oleh pejabat pembuat komitmen selaku kepala dinas.

Tindakan atau perbuatan kepala dinas menandatangani perjanjian merupakan 
kewenangan mandiri dari kepala dinas yang akibat hukumnya ditanggungnya sendiri dalam batas-batas kewenangan yang dimilikinya berdasarkan peraturan perundang-undangan yang mengaturnya. Hal demikian merujuk pada konsep delegasi kewenangan sebagaimana telah penulis uraikan di atas.

Merujuk pada konstruksi hukum yang dibangun hakim dalam putusannya, tidak diragukan lagi bahwa kepala dinas terbukti melakukan wanprestasi atas Surat Perjanjian Nomor 027/06-10/KKPK/Dinkes/VI/2013 yang dibuat dan ditandatangani oleh pejabat pembuat komitmen untuk dan atas nama Dinas Kesehatan selaku pengguna anggaran/pengguna barang dengan PT. TJP. Oleh karena itu, perbuatan wanprestasi tersebut harus menjadi tanggung jawab jabatan kepala dinas dalam batasbatas kewenangan yang dimilikinya menurut konsep kewenangan dalam hukum administrasi negara. Konsekuensi hukumnya, kepala dinas harus memenuhi prestasi yang telah diberikan penggugat sebagai bentuk pemulihan kerugian yang timbul dari perbuatan ingkar janji terhadap perjanjian yang dibuat.

Bagi walikota selaku tergugat II, tidak ada dasar hukumnya apabila dibebankan tanggung jawab hukum atas perbuatan wanprestasi yang dilakukan oleh kepala dinas. Pembebanan tanggung jawab yang dilakukan pejabat pemerintah sekalipun tindakan atau perbuatan tersebut dilakukan dalam ranah keperdataan harus disesuaikan dengan konsep pertanggungjawaban jabatan pemerintahan sebagaimana diajarkan dalam hukum administrasi negara. Dengan perkataan lain, majelis hakim semestinya memisahkan bentuk tanggung jawab hukum pejabat pemerintah dalam ranah keperdataan.
Majelis hakim semestinya memahami konsep tentang sumber dan cara memperoleh kewenangan organ/pejabat pemerintahan sebagaimana diajarkan dalam hukum administrasi negara ketika hendak mengkonstruksinya siapa yang bertanggung jawab atas tindakan atau perbuatan wanprestasi yang dilakukan oleh pejabat pemerintahan dalam pelaksanaan perjanjian pemborongan. Hal demikian dimaksudkan agar institusi peradilan melalui para hakimnya tidak ikut andil menciptakan kekacauan dalam lapangan hukum, terutama dalam rangka pelaksanaan ajaran-ajaran hukum secara in concreto.

Merujuk pada perspektif ajaran hukum administrasi negara dan hukum perdata sebagaimana telah diuraikan di atas, terlihat bahwa tafsir hakim hanya bersandar pada teks normatif belaka dan belum mempu menangkap makna konteks dan kontekstualisasinya. Dalam memutus perkara di atas, hakim belum memaknai teks perundang-undangan yang terkait pembebanan tanggung jawab kepala daerah secara kritis, sehingga belum mampu menjawab rasa keadilan masyarakat.

Menurut Sarmadi (2012: 341), pemaknaan kritis terhadap teks perundang-undangan agar mencapai keadilan penting dilakukan oleh hakim dengan beberapa alasan. Pertama, teks hukum tidak berdiri sendiri akan tetapi harus dipahami maksud atau tujuan besar dari pembuat teks hukum tersebut. Kedua, setiap teks hukum selalu memiliki tujuan dan objek yang ingin dicapainya, perlu melihat hubungan antara pasal dengan tujuan besar diberlakukannya peraturan tersebut. Ketiga, adanya kemungkinan kesalahankesalahan teks atas suatu hukum karena berlawanan dengan rasa keadilan masyarakat. Keempat, berani mengkritik teks hukum untuk 
suatu kesempurnaan pelaksanaan hukum, menggali keadilan sekali pun di luar teks hukum demi keadilan, moral, dan hati nurani rakyat.

Interpretasi yang benar terhadap teks hukum harus selalu berhubungan dengan isi (kaidah hukumnya), baik yang tersurat maupun yang tersirat, atau antara bunyi hukum dan semangat hukum (Oktoberina \& Savitri, 2008: 90). Guna mengungkap makna sesungguhnya sebuah teks hukum, konstruksi hukum secara cermat dan tepat diperlukan. Dalam proses tersebut makna teks atau wacana secara keseluruhan harus ikut dipertimbangkan. Dengan demikian pertimbangan makna sebuah teks bukanlah parsial dan fragmentaris melainkan holistik dan integratif.

Perlu juga diselidiki apakah makna teks tersebut mutlak atau relatif, universal atau parsial. Efek-efek yang dihasilkan dari konstruksi dan interpretasi teks tersebut itu pun harus ikut dipertimbangkan (efek minimum atau maksimum). Di sini, lagi-lagi kepentingan masyarakat yang lebih besar tidak boleh dikalahkan demi kepentingan yang lebih spesifik dan terbatas (Weruin et al., 2016: 111). Hanya dengan pemaknaan demikian yang mampu melahirkan karakter putusan hakim yang bermakna secara hukum, sekaligus mampu menangkap dan merawat nilai-nilai keadilan hukum.

\section{KESIMPULAN}

Bersandar pada interpretasi hermeneutika hukum, majelis hakim tampaknya telah keliru menafsirkan makna tanggung jawab walikota secara keperdataan akibat wanprestasi yang dilakukan kepala dinas dalam Putusan Nomor 72/PDT.G/2014/PN.TGR. Dalam telaah hukum administrasi negara, walikota selaku pemegang kekuasaan keuangan daerah tidak dapat dimintai tanggung jawab secara keperdataan akibat perbuatan wanprestasi yang dilakukan kepala dinas selaku pejabat pembuat komitmen.

Secara yuridis, walikota adalah pemegang kekuasaan atas pengelolaan keuangan daerah, namun dalam pelaksanaannya telah dilimpahkan atau didelegasikan kepada kepala dinas sebagaimana ditentukan dalam Peraturan Pemerintah Nomor 58 Tahun 2005 dan Peraturan Menteri Dalam Negeri Nomor 13 Tahun 2006 sebagai peraturan turunannya. Dengan adanya pendelegasian kewenangan dari walikota kepada kepala dinas, maka yang bertanggung jawab secara hukum atas semua pengelolaan keuangan daerah dibebankan kepada kepala dinas selaku pengguna anggaran/pengguna barang. Demikian pula ditinjau dari perspektif ajaran hukum perdata bahwa perbuatan wanprestasi yang dilakukan kepala dinas juga tidak dapat dibebankan kepada walikota sebagaimana ditentukan dalam Pasal 1340 KUHPerdata.

Pasal ini menjadi pembatas daya ikat dan keberlakukan perjanjian bagi para pihak, yakni sebatas bagi para pihak yang membuatnya. Walikota bukanlah merupakan pihak dalam pelaksanaan ikatan/perjanjian yang dibuat oleh pejabat pembuat komitmen. Tindakan atau perbuatan kepala dinas menandatanganiperjanjian merupakan kewenangan mandiri dari kepala dinas yang akibat hukumnya ditanggungnya sendiri dalam batas-batas kewenangan yang dimilikinya berdasarkan peraturan perundangundangan yang mengaturnya.

Interpretasi yang demikian, hendaknya hakim, ketika memeriksa, mengadili, dan memutus perkara yang berkenaan dengan 
tindakan atau perbuatan hukum pemerintahan dalam lapangan hukum privat, hendaknya juga memahami dengan benar konsep-konsep, teoriteori, dan ajaran-ajaran dalam lingkup hukum administrasi negara, sehingga rasa keadilan para pencari keadilan dapat senantiasa terjaga dan terpelihara secara baik. Setiap hakim dituntut untuk memahami dengan benar semua ajaranajaran hukum, tidak hanya dibatasi kamar yang menjadi kewenangannya yaitu perkara yang berkarakter perdata saja, tetapi juga menguasai ajaran-ajaran ilmu hukum dalam lingkup bidang hukum pidana maupun hukum administrasi negara.

\section{DAFTAR ACUAN}

Afrizal. (2016). Metode penelitian kualitatif: Sebuah upaya mendukung penggunaan penelitian kualitatif dalam berbagai disiplin ilmu. Jakarta: Rajawali Press.

Bachtiar. (2017). Kekuasaan \& pertanggungjawaban presiden dalam konstruksi politik hukum konstitusi Negara Republik Indonesia. Disertasi. Fakultas Hukum Universitas Trisakti.

Djojodirdjo, M. (1979). Perbuatan melawan hukum. Jakarta: Pradnya Paramita.

Firdaus. (2007). Pertanggungjawaban presiden dalam negara hukum demokrasi. Bandung: Yrama Widya.

Hadjon, P.M. et. al. (1993). Pengantar hukum administrasi Indonesia. Yogyakarta: Gadjah Mada University Press.

Hidjaz, K. (2010). Efektivitas penyelenggaraan kewenangan dalam sistem pemerintahan daerah di Indonesia. Makassar: Pustaka Refleksi.
Ilmar, A. (2014). Hukum tata pemerintahan. Jakarta: Kencana.

Meliala, D.S. (2012). Hukum perikatan dalam prespektif $B W$. Bandung: Nuansa Aulia.

Musyahadah, R.A. (2013, Mei). Hermeneutika hukum sebagai alternatif metode penemuan hukum bagi hakim untuk menunjang keadilan gender. Jurnal Dinamika Hukum, 13(2), 293-306.

Nasution, M. (2011). Pertanggungjawaban gubernur dalam Negara Kesatuan Indonesia. Jakarta: Sofmedia.

Newton, K., \& Van Deth, J.W. (2015). Perbandingan sistem politik: Teori \& fakta. Muttaqin, I. (Ed.). Bandung: Nusa Media.

Oktoberina, S.R., \& Savitri, N. (Eds). (2008). Butirbutir pemikiran dalam hukum; Memperingati 70 tahun Prof. Dr. B. Arief Sidharta, SH. Bandung: Refika Aditama.

Raharjo, H. (2009). Hukum perjanjian di Indonesia. Yogyakarta: Pustaka Yustitia.

Rasjid, R. (2007). Makna pemerintahan tinjauan dari segi etika \& kepemimpinan. Jakarta: Yasrif Watampone.

Ridwan HR. (2014). Hukum administrasi negara. Jakarta: Rajawali Pers.

Sarmadi, A.S. (2012, Mei). Membebaskan positivism hukum ke ranah hukum progresif (Studi pembacaan teks hukum bagi penegak hukum). Jurnal Dinamika Hukum, 12(2), 332-342.

Slamet, S.R. (2016， Desember). Kesempurnaan kontrak kerja konstruksi menghindari sengketa. Lex Jurnalica, 13(3), 191-208.

Solihah, I. (2016, Desember). Kebijakan hukum pembangunan kawasan perbatasan melalui infrastruktur berbasis teknologi. Jurnal Rechtsvinding, 5(3), 303-321. 
Suhendar. (2015). Konsep kerugian keuangan negara, pendekatan hukum pidana, hukum administrasi negara,\& pidana khusus korupsi. Malang: Setara Press.

Tahir, M.M. (2015, Januari). Good urban governance: Peran pemerintah dalam pembangunan wilayah kecamatan di Kota Makassar. Government: Jurnal Ilmu Pemerintahan, 8(1), 9-15.

Van Apeldoorn, L.J. (2000). Pengantar ilmu hukum. Jakarta: Pradnya Paramita.

Weruin, U.U. et al. (2016, Maret). Hermeneutika hukum: Prinsip \& kaidah interpretasi hukum. Jurnal Konstitusi, 13(1), 95-123.

Wiradipradja, E.S. (2015). Penuntun praktis metode penelitian \& penulisan karya ilmiah hukum. Bandung: Keni Media. 